\title{
PENGARUH KECERDASAN EMOSIONAL DAN TINGKAT DAYA JUANG TERHADAP PRESTASI BELAJAR IPS PADA SISWA SMA DI JAKARTA SELATAN TAHUN AJARAN 2014/2015
}

\author{
Sigit Indra Prianto \\ Dosen Program Studi Teknik Informatika Universitas Indraprasta PGRI \\ Email:sigitsoebroto@gmail.com / 085694623805
}

\begin{abstract}
Abstrak
Penelitian ini dilaksanakanpada siswa kelas XI di Sekolah Menengah Atas Negeri 38, 49, dan 109 Jakarta Selatan Pada Tahun Ajaran 2013/2014. Populasi berjumlah 785 siswa. Sampel di dalam penelitian ini berjumlah 100 siswa yang diambil dengan menggunakan random sampling. Instrumen yang digunakan dalam penelitian ini dengan menggunakan angket. Instrumen penelitian ini telah diuji cobakan dengan pengujian validitas dan reliabilitas mengunakan Program Microsoft Excel 2007.Metode penelitian yang digunakan adalah survei. Teknik analisis data yang dilakukan dalam penelitian ini, yaitu: regresi berganda dan korelasi berganda IPS, Uji F dan t. Hasil penelitian adalah sebagai berikut:koefisien korelasi ganda pengaruh variabel bebas kecerdasaan emosional dan daya juang secara bersama-sama terhadap prestasi belajar IPS siswa adalah sebesar 0,838. Koefisien determinasinya sebesar 70,2 \%,sisanya 29,8 \% karena pengaruh variabel lain. Persamaan garis regresi yang mempresentasikan pengaruh variabel $\mathrm{X}_{1}$ dan $\mathrm{X}_{2}$ terhadap variabel $\mathrm{Y}$,yaitu $\hat{\mathrm{Y}}=19,979+0,043 \mathrm{X}_{1}+0,752 \mathrm{X}_{2}$. Hasil pengujian hipotesis: 1 . Terdapat pengaruh kecerdasaan emosional dan daya juang secara bersama-sama terhadap prestasi belajar IPS siswa yang dibuktikan dengan nilai sig $=0,000<0,05$ dan $\mathrm{F}$ hitung $=114,219>\mathrm{F}$ tabel $=3,09$. 2. Terdapat pengaruh yang tidak signifikan kecerdasaan emosional terhadap prestasi belajar IPS yang dibuktikan dengan nilai Sig $=0,325>0,05$ dan $\mathrm{t}$ hitung $=0,990<\mathrm{t}$ tabel $=1,66$. 3. Terdapat pengaruh yang signifikan daya juang terhadap prestasi belajar IPS yang dibuktikan dengan nilai Sig $=0,000<0,05$ dan $\mathrm{t}$ hitung = 15, $102>$ t tabel = 1,66.
\end{abstract}

Kata Kunci: Kecerdasaan Emosional, Tingkat Daya Juang, dan Prestasi Belajar IPS.

\section{PENDAHULUAN}

Pendidikan pada hakikatnya memiliki peran penting dalam kehidupan manusia. Salah satunya sebagai wahana yang berfungsi menjadikan manusia menjadi lebih baik dan sempurna dari sebelumnya. Disisi yang lain, proses kegiatan pendidikan diharapkandapat “memanusiakan manusia”. Hal ini tidak lepas bahwa manusia sebagai makhluk individu tidak dapat hidup sendiri. Sebagai makhluk sosial, manusia selalu berinteraksi dengan sesama manusia lain serta lingkungan sekitarnya. Interaksi inilah yang menciptakan hubungan satu dengan lain, bahkan menciptakan saling ketergantungan.Dalam berinteraksi dan bersosialisasi menjadisuku atau bangsa, hubungan emosional yang dibangun manusia memunculkan potensi masalah-masalah yang berkaitan dengan masalah sosial. Diperlukan pengetahuan sosial yang komprehensif untuk memastikan hubungan interaksi antar manusia terjadi dengan baik dan tidak menimbulkan konflik sosial. 
Pendidikan Ilmu Pengetahuan Sosial (IPS) dapat memberikan kontribusi dalam mengatasi masalah sosial, sebab pendidikan IPS memiliki fungsi dan peran dalam meningkatkan Sumber Daya Insani untuk memperoleh bekal pengetahuan tentang harkat dan martabat manusia sebagai mahluk sosial, keterampilan menerapkan pengetahuan tersebut dan mampu bersikap berdasarkan nilai dan norma sehingga mampu hidup bermasyarakat. Hal ini sejalan dengan pendapat (Goleman, 2000:44) bahwa kecerdasan intelektual (IQ) hanya berkontribusi 20 persen bagi kesuksesan seseorang, sedangkan 80 persen lebih banyak dipengaruhi oleh faktor-faktor seperti emotional quotient (EQ) yakni kemampuan memotivasi diri sendiri, mengatasi frustasi, mengontrol desakan hati, mengatur suasana hati (mood), berempati serta kemampuan bekerja sama.Pendidikan di lingkungan sekolah saat ini tidak hanya perlu mengembangkan rational intelligence namun juga perlu mengembangkan emotional intelligence siswa.

Pendapat Goleman juga sejalan dengan hasil penelitian yang dilakukan oleh Nasution (2009: 120) dengan lokus penelitian di Fakultas Ekonomi Universitas Muhammadiyah Sumatera Utara serta penelitian kedua yang dilakukan oleh Mutia (2015: 649) dengan studi empiris mahasiswa akuntasi Perguruan Tinggi di Kota Padang. Hasil kesimpulan dari dua penelitian ini sama-sama menyatakan bahwa Kecerdasan Emosional memiliki pengaruh langsung yang signifikan terhadap pemahaman akuntasi mahasiswa. Dimana semakin tinggi kecerdasan emosional mahasiswa maka semakin baik tingkat pemahaman akuntansi mahasiswa.

Peserta didik selama ini banyak mengalami kondisi psikologi yang mudah menyerah ketika menghadapi soal-soal yang sulit dan terkadang menyerah sebelum bertanding. Oleh karena itu, tingkat daya juang siswa juga perlu ditingkatkan dengan selalu memberikan motivasi-motivasi yang positif di dalam meningkatkan semangat siswa dalam meraih sesuatu yang baik. Dengan adanya kecerdasan emosional dan tingkat daya juang yang baik diharapkan peserta didik mampu menguasai dan mengimplementasikan Ilmu Pengetahuan Sosial di lingkungannya sehingga permasalahan sosial yang dihadapi dapat diatasi dengan baik. 


\section{TINJAUAN PUSTAKA}

\section{Hakikat Prestasi Belajar}

Prestasi belajar merupakan hasil nilai yang diperoleh siswa dari hasil evaluasi setelah kegiatan proses pembelajaran. Menurut Winkel (1991: 28), ”Hasil belajar adalah bukti keberhasilan dan usaha yang dilakuakan dan merupakan kecakapan yang diperoleh melalui kegiatan pembelajaran di sekolah yang dinyatakan dengan angka”. Selanjutnya Soemantri (2001:1) menjelaskan hasil belajar merupakan suatu indikator dari perubahan yang terjadi pada diri siswa setelah mengalami proses belajar dimana untuk mengungkapnya biasanya menggunakan suatu alat penilaian yang ditetapkan sekolah oleh guru. Dalam dunia pendidikan khususnya sekolah hasil belajar merupakan nilai yang diperoleh siswa terhadap suatu mata pelajaran tertentu.

\section{Kecerdasan Emosional}

Kecerdasan emosional menurut Winarno dan Saksono, (2001:8) adalah kemampuan merasakan, memahami, dan secara efektif menerapkan daya dan kepekaan emosi sebagai sumber energi, informasi, koneksi, dan pengaruh yang manusiawi'’.Berdasarkan pengertian ini, dapat disimpulkan kita bukan hanya otak analitis yang terletak di bagian otak sebelah kiri kita tapi juga emosi dan intuisi, indra dan kecerdasan emosional yang berlokasi dalam otak sebelah kanan yang fungsinya lebih integratif. Adapun Goleman (2002: 512-514) memberikan pengertian kecerdasan emosional yaitu kemampuan seseorang mengatur kehidupan emosinya dengan inteligensi menjaga keselarasan emosi dan pengungkapannya melalui:

1. Pengenalan diri (Self awareness);

2. Pengendalian diri (self regulation);

3. Motivasi (motivation);

4. Empati (empathy);

5. Keterampilan sosial (social skills).

\section{Hakikat Daya Juang}

Adversity quotient atau daya juang adalah bentuk kecerdasan selain IQ, SQ, dan EQ yang ditujukan untuk mengatasi kesulitan. Nashori (2007: 47) berpendapat bahwa “adversity quotient merupakan kemampuan seseorang dalam menggunakan kecerdasannya untuk mengarahkan, mengubah cara berfikir dan tindakannya ketika menghadapi hambatan dan kesulitan yang bisa menyengsarakan dirinya”. Adapun Leman (2007: 115) mendefinisikan adversity quotient secara ringkas, yaitu sebagai kemampuan seseorang untuk menghadapi masalah. Beberapa definisi di atas yang 
cukup beragam, terdapat fokus atau titik tekan, yaitu kemampuan yang dimiliki seseorang, baik fisik ataupun psikis dalam menghadapi problematika atau permasalahan yang sedang dialami.

Adapun Faktor-faktor pembentuk adversity quotient menurut Stoltz (2000:92) adalah daya saing, tingkat kesulitan pekerjaan yang dihadapi, motivasi yang kuat baik dari dalam maupun dari luar, berani mengambil peluang dan resiko, memperbaiki pekerjaan terus-menerus agar kemampuan di dalam bekerja semakin berkembang, tekun didalam mengerjakan pekerjaanya, dan optimis didalam bekerja dan selalu belajar demi meningkatkan kompetensi.

\section{METODE}

Penelitian ini menggunakan metode deskriptif korelasional dengan pendekatan survei. Sebagaimana yang diungkapkan oleh M. Iqbal Hasan (2002:23) bahwa pada metode deskriptif data dihimpun, disusun secara sistematis, faktual, dan cermat, namun tidak dijelaskan mengenai hubungan di antara variabel, tidak melakukan uji hipotesis, sedangkan pada metode korelasional hubungan antara variabel diteliti dan dijelaskan. Hubungan yang dicari ini disebut sebagai korelasi.

Adapun variabel penelitian ini yaitu variabel terikat (dependent variable) adalah prestasi belajar IPS siswa (Y) dan variabel bebas (independent variable) adalah kecerdasaan emosional (X1)dan tingkat daya juang (X2)”.Adapun model konstelasi hubungan antar variabel dalam penelitian ini adalah sebagai berikut:

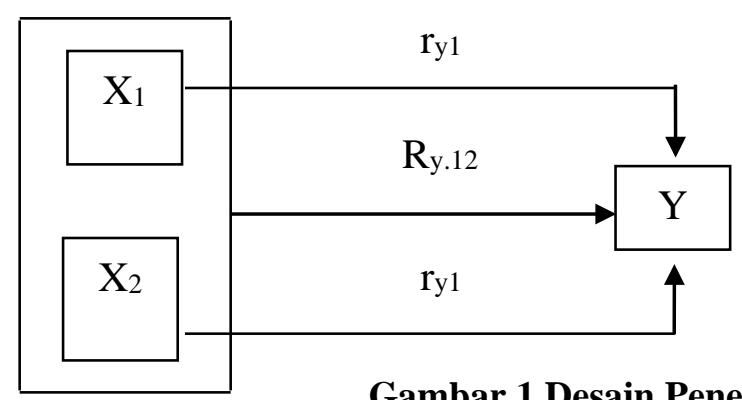

\section{Gambar.1 Desain Penelitian}

Keterangan :

$\mathrm{X}_{1}=$ Kecerdasaan emosional

$\mathrm{X}_{2}=$ Tingkat Daya juang

$\mathrm{Y}=$ Prestasi Belajar IPSSiswa 
Populasi dalam penelitian ini adalah seluruh seluruh siswa kelas XI SMA Negeri 38 yang berjumlah 250, SMAN 49 yang berjumlah 270, dan SMA N 109 yang berjumlah 265 di Jakarta Selatan. Semua total populasi target adalah 785. Peneliti menentukan sampel dalam penelitian ini sebanyak 100 siswa yang diambil secara acak atau random sampling. Instrumen yang digunakan adalah kuesioner untuk mengumpulkan data variabel bebas dan variabel terikat. Pengembangan instrumen dibuat melalui tahapan antara lain: (1) menyusun indikator variabel penelitian; (2) menyusun kisi-kisi intrumen; (3) menyusun item; (4) melakukan uji coba penelitian; (5) melakukan pengujian validitas serta reabilitas instrumen.

\section{HASIL DAN PEMBAHASAN}

Dari hasil penelitian terhadap 100 siswa, maka diperoleh informasi umum sebagai berikut:

Tabel 1. Deskripsi Data Penelitian

\begin{tabular}{|c|c|c|c|c|}
\hline \multicolumn{5}{|c|}{ Statistics } \\
\hline & & $\mathrm{X} 1$ & $\mathrm{X} 2$ & $\mathrm{Y}$ \\
\hline \multirow[t]{2}{*}{$\mathrm{N}$} & Valid & 100 & 100 & 100 \\
\hline & Missing & 0 & 0 & 0 \\
\hline \multicolumn{2}{|c|}{ Mean } & 60,89 & 77,57 & 80,90 \\
\hline \multicolumn{2}{|c|}{ Median } & 61,50 & 78,00 & 82,00 \\
\hline \multicolumn{2}{|c|}{ Mode } & 59 & 81 & 82 \\
\hline \multicolumn{2}{|c|}{ Std. Deviation } & 5,829 & 5,058 & 4,541 \\
\hline \multicolumn{2}{|c|}{ Variance } & 33,978 & 25,581 & 20,616 \\
\hline \multicolumn{2}{|c|}{ Range } & 32 & 21 & 20 \\
\hline \multicolumn{2}{|c|}{ Minimum } & 45 & 68 & 70 \\
\hline \multicolumn{2}{|c|}{ Maximum } & 77 & 89 & 90 \\
\hline
\end{tabular}

Dari tabel 1. Diketahui data prestasi belajar IPS siswa mempunyai rata-rata 80,90, median 82,00, modus 82, standar deviasi 4,541, varians 20,616, rentang 20, nilai terendah 70, dan nilai tertinggi 90. Dari deskripsi data tersebut, dapat dilihat bahwa nilai rata-rata dan median hampir sama, yaitu 80,90 dan 82,00. Hal ini menunjukan bahwa data prestasi belajar IPS siswa pada penelitian ini cukup representatif. Dari tabel 1. Juga menunjukkan bahwa data kecerdasaan emosional mempunyai rata-rata 60,89, median 61,50, modus 59, standar deviasi 5,829, varians 33,978, rentang 32, nilai terendah 45 , dan nilai tertinggi 77. Dari deskripsi data tersebut, dapat dilihat bahwa nilai rata-rata dan median hampir sama, yaitu 60,89 dan 61,50. Hal ini menunjukan bahwa data kecerdasaan emosional pada penelitian ini cukup representatif. Dari tabel 1. Diketahui tingkat daya juang mempunyai rata-rata 77,57, median 78,00, modus 81 , standar deviasi 
5,058, varians 25,581, rentang 21, nilai terendah 68, dan nilai tertinggi 89. Dari deskripsi data tersebut, dapat dilihat bahwa nilai rata-rata dan median hampir sama, yaitu 77,57 dan 78,00. Hal ini menunjukan bahwa data tingkat daya juang pada penelitian ini cukup representatif.

\section{Pengujian Linieritas Garis Regresi}

Hasil perhitungan pengujian linieritas garis regresi hubungan antara variabel $\mathrm{X}_{1}$ dengan variabel Y diperoleh hasil sebagai berikut:

Tabel 2.Hasil Perhitungan Linieritas Garis Regresi Pengaruh $\mathrm{X}_{1}$ terhadap Y.

ANOVA Table

\begin{tabular}{|c|c|c|c|c|c|c|c|}
\hline & & & Sum of Squares & $\mathrm{df}$ & Mean Square & $\mathrm{F}$ & Sig. \\
\hline \multirow[t]{5}{*}{$\mathrm{Y} * \mathrm{X} 1$} & Between & (Combined) & 649,064 & 24 & 27,044 & 1,457 & ,111 \\
\hline & Groups & Linearity & 2,245 & 1 & 2,245 & ,121 & ,729 \\
\hline & & Deviation from Linearity & 646,819 & 23 & 28,123 & 1,515 & ,092 \\
\hline & Within Groups & & 1391,936 & 75 & 18,559 & & \\
\hline & Total & & 2041,000 & 99 & & & \\
\hline
\end{tabular}

Pada tabel 2. di atas terlihat bahwa nilai pada kolom Sig baris Deviation from linierity adalah 0,92 lebih besar dari 0,05,sehingga Ho diterima, dengan kata lain bahwa garis regresi pengaruh variabel X1 terhadap variabel Y tersebut adalah linier.

Hasil perhitungan pengujian linieritas garis regresi hubungan antara variabel $\mathrm{X}_{2}$ dengan variabel Y diperoleh hasil:

Tabel 3.Hasil Perhitungan Linieritas Garis Regresi Pengaruh $\mathrm{X}_{2}$ terhadap Y ANOVA Table

\begin{tabular}{|c|c|c|c|c|c|c|c|}
\hline & & & Sum of Squares & df & Mean Square & $\mathrm{F}$ & Sig. \\
\hline \multirow[t]{5}{*}{$\mathrm{Y} * \mathrm{X} 2$} & Between Groups & (Combined) & 1644,851 & 20 & 82,243 & 16,401 & 000 \\
\hline & & Linearity & 1426,514 & 1 & 1426,514 & 284,475 &, 000 \\
\hline & & Deviation from Linearity & 218,337 & 19 & 11,491 & 2,292 & 006 \\
\hline & Within Groups & & 396,149 & 79 & 5,015 & & \\
\hline & Total & & 2041,000 & 99 & & & \\
\hline
\end{tabular}

Pada tabel 3. di atas terlihat bahwa nilai pada kolom Sig baris Deviation from linierity adalah 0,006 lebihkecil dari 0,05,sehingga Ho ditolak,dengan kata lain bahwa garis regresi pengaruh variabel $\mathrm{X}_{2}$ terhadap variabel $\mathrm{Y}$ tersebut adalah tidak linier. 


\section{Hasil Perhitungan Dan Pengujian Data Penelitian}

Tabel 4.Hasil Perhitungan Koefisien Korelasi

Pengaruh Variabel X1, dan X2, terhadap Y

Model Summary

\begin{tabular}{lcccc}
\hline Model & $\mathrm{R}$ & $\mathrm{R}$ Square & $\begin{array}{c}\text { Adjusted R } \\
\text { Square }\end{array}$ & $\begin{array}{c}\text { Std. Error of the } \\
\text { Estimate }\end{array}$ \\
\hline 1 &, $838^{\mathrm{a}}$ &, 702 &, 696 & 2,504 \\
\hline a. Predictors: (Constant), X2, X1 & &
\end{tabular}

Tabel 5. Rekapitulasi Hasil Perhitungan Pengujian Signifikasi Koefisien Regresi Pengaruh Variabel X1,dan X2 terhadap Varibel Y

\begin{tabular}{rlrcccc}
\multicolumn{7}{c}{ ANOVA $^{\mathbf{a}}$} \\
\hline 1 & Model & Sum of Squares & df & Mean Square & F & Sig. \\
\hline & Regression & 1432,660 & 2 & 716,330 & 114,219 &, $000^{\mathrm{b}}$ \\
& Residual & 608,340 & 97 & 6,272 & & \\
& Total & 2041,000 & 99 & & & \\
\hline
\end{tabular}

a. Dependent Variable: $\mathrm{Y}$

b. Predictors: (Constant), X2, X1

Tabel 6.Rekapitulasi Hasil Perhitungan Persamaan Garis Regresi Pengaruh Variabel X1,dan X2 terhadap Varibel Y

\begin{tabular}{|c|c|c|c|c|c|c|}
\hline \multicolumn{7}{|c|}{ Coefficients $^{\mathbf{a}}$} \\
\hline & & \multicolumn{2}{|c|}{ Unstandardized Coefficients } & \multicolumn{2}{|l|}{$\begin{array}{l}\text { Standardized } \\
\text { Coefficients }\end{array}$} & \multirow[b]{2}{*}{ Sig. } \\
\hline & Model & $\mathrm{B}$ & Std. Error & Beta & $\mathrm{t}$ & \\
\hline \multirow[t]{3}{*}{1} & (Constant) & 19,979 & 4,735 & & 4,220 & ,000 \\
\hline & $\mathrm{X} 1$ &, 043 & ,043 & ,055 & ,990 & 325 \\
\hline & $\mathrm{X} 2$ & ,752 & ,050 & ,837 & 15,102 & ,000 \\
\hline
\end{tabular}

a. Dependent Variable: Y

Dari hasil perhitungan dan pengujian hipotesis pada tabel (4) (5) dan (6), dapat diinterpretasikan sebagai berikut:

\section{Pengaruh Secara Bersama-sama Kecerdasaan Emosional dan Tingkat Daya Juang Terhadap Prestasi Belajar IPS}

Koefisien korelasi ganda pengaruh variabel bebas kecerdasaan emosional dan tingkat daya juang secara bersama-sama terhadap prestasi belajar IPS siswa adalah sebesar 0,838 yang artinya hubungan tersebut sangat kuat. Hubungan ini artinya apabila variabel kecerdasaan emosional dan tingkat daya juang naik maka variabel prestasi belajar IPS akan naik dan apabila variabel kecerdasaan emosional dan tingkat daya juang turun maka variabel prestasi belajar IPS juga akan turun. 
Koefisien determinasinya sebesar 70,2 \%, sisanya 29,8 \% karena pengaruh variabel lain. Ini artinya sumbangan variabel kecerdasaan emosional dan tingkat daya juang terhadap peningkatan prestasi belajar IPS siswa adalah 70,2 \%, sisanya 29,8 \% dari variabel selain kedua variabel tersebut.

Variabel kecerdasaan emosinal dan tingkat daya juang hanya mampu memberikan sumbangan bagi peningkatan prestasi belajar IPS sebesar 70,2\% dan 29,8\% dari variabel lain, seperti motivasi belajar, disiplin, dan penggunaan metode pembelajaran.

Pengujian analisis regresi diperoleh hasil perhitungan diperoleh persamaan garis regresi yang mempresentasikan pengaruh variabel $\mathrm{X}_{1}$ dan $\mathrm{X}_{2}$ terhadap variabel $\mathrm{Y}$,yaitu $=19,979+0,043 \mathrm{X}_{1}+0,752 \mathrm{X}_{2}$. Artinya setiap kenaikan satu unit variabel kecerdasaan emosional akan meningkatkan prestasi belajar IPS sebesar 0,043 dan setiap kenaikan satu unit variabel tingkat daya juang akan meningkatkan prestasi belajar IPS sebesar 0,752 dan apabila tidak ada variabel kecerdasaan emosional dan tingkat daya juang maka prestasi belajar IPS akan konstan sebesar 19,979.

Pengujian hipotesis penelitian yaitu nilai sig $=0,000$ dan $\mathrm{F}$ hitung $=114$, 219, sedangkan $\mathrm{F}$ tabel = 3,09. Maka Ho ditolak yang berarti bahwa koefisien regresi tersebut signifikan. Berarti terdapat pengaruh kecerdasaan emosional dan tingkat daya juang secara bersama-sama terhadap prestasi belajar IPS siswa.

Prestasi belajar IPS dapat ditingkatkan dengan memaksimalkan variabel kecerdasaan emosional dan tingkat daya juang secara bersama-sama. Siswa yang memiliki kecerdasaan emosional yang baik dengan disertai tingkat daya juang yang tinggi akan memberikan pengaruh bagi peningkatan prestasi belajar IPS.

\section{Pengaruh Kecerdasaan Emosional Terhadap Prestasi Belajar IPS}

Nilai Sig $=0,325$ dan thitung $=0,990$, sedangkan $\mathrm{t}$ tabel $=1,66$. Karena nilai Sig $>$ 0,05 dan t hitung < t tabel, maka Ho diterima yang berarti terdapat pengaruh yang tidak signifikan kecerdasaan emosional terhadap prestasi belajar IPS.

Dari hasil pengujian hipotesis dapat disimpulkan bahwa terdapat pengaruh tidak yang signifikan kecerdasaan emosional terhadap prestasi belajar IPS.

Siswa yang memiliki kecerdasaan emosional yang baik, tetapi tidak memiliki tingkat daya juang yang tinggi maka akan berpengaruh tidak signifikan bagi peningkatan prestasi belajar IPS. Siswa yang memiliki kecerdasaan emosional yang 
baik akan cenderung berhati-hati menjawab pertanyaan sehingga pada akhirnya akan banyak membuang waktu sehingga tidak akan efisien dalam menjawab pertanyaan.

\section{Pengaruh Tingkat Daya Juang Terhadap Prestasi Belajar IPS}

Nilai Sig $=0,000$ dan t hitung $=15,102$, sedangkan $\mathrm{t}$ tabel $=1,66$. Karena nilai Sig $<0,05$ dan $\mathrm{t}$ hitung $>\mathrm{t}$ tabel, maka Ho ditolak yang berarti terdapat pengaruh yang signifikan tingkat daya juang terhadap prestasi belajar IPS.

Dari hasil pengujian hipotesis maka dapat disimpulkan bahwa terdapat pengaruh yang signifikan tingkat daya juang terhadap prestasi belajar IPS. Tingkat daya juang pada siswa dapat meningkatkan prestasi belajar IPS siswa. Siswa yang memiliki tingkat daya juang tinggi akan selalu berusaha untuk dapat memperoleh prestasi belajar IPS yang tinggi. Tingkat daya juang merupakan kekuatan yang dimiliki oleh siswa yang dapat digunakan dalam meningkatkan prestasi belajar IPS.

\section{SIMPULAN}

1. Terdapat pengaruh yang signifikan kecerdasaan emosional dan tingkat daya juang secara bersama-sama terhadap prestasi belajar IPS siswa yang dibuktikan dengan nilai Sig $=0,000$ $<0,05$ dan $\mathrm{F}$ hitung $=114,219>\mathrm{F}$ tabel $=3,09$.

2. Terdapat pengaruh yang tidak signifikan kecerdasaan emosional terhadap prestasi belajar IPS yang dibuktikan dengan nilai Sig $=0,325>0,05$ dan $\mathrm{t}$ hitung $=0,990<\mathrm{t}$ tabel $=1,66$.

3. Terdapat pengaruh yang signifikan tingkat daya juang terhadap prestasi belajar IPS yang dibuktikan dengan nilai Sig $=0,000<0,05$ dan $\mathrm{t}$ hitung $=15,102>\mathrm{t}$ tabel $=1,66$.

\section{DAFTAR PUSTAKA}

Goleman, Daniel. 2000. Emitional Intelligence (terjemahan). Jakarta: PT. Gramedia Pustaka Utama.

Goleman, Daniel. 2002. Emotional Intelligence (terjemahan). Jakata : PT Gramedia Pustaka Utama.

Hasan, M.Iqbal. (2002). Pokok-pokok Materi Metodologi Penelitian dan Aplikasinya. Jakarta: PenerbitGhalia Indonesia.

Leman. 2007. Memahami Adversity Quotient. Anima (Indonesian PsychologicalJournal). 
Mutia, Atika. 2015. Pengaruh Kecerdasan Emosional dan Perilaku Belajar terhadap Tingkat Pemahaman Akuntansi Mahasiswa (Studi Empiris Mahasiswa Akuntansi Perguruan Tinggi di Kota Padang). Padang: Jurnal WRA Vol 3, No 2, Oktober 2015.

Nashori. 2007. Adversity Quotient: Hambatan Menjadi Peluang. Jakarta:PTGrasindo.

Nasution, F. Arifin. 2009. Pengeruh Kecerdasan Emosional dan Kepercayaan Diri terhadap Tingkat Pemahaman Akuntansi Mahasiswa UMSU. Sumatera Utara: Jurnal Riset Akuntansi Dan Bisnis, Vol. 9 No. 2 / September 2009. Fakultan Ekonomi-Universitas Muhammadiyah Sumatera Utara.

Nuraini, Maya. 2007. Pengaruh Kecerdasan Emosional dan Minat Belajar Mahasiswa Akuntansi Terhadap Tingkat Pemahaman Bahasa Indonesia. Jurnal Beta, Gresik.

Soemantri. 2001. Menggagas Pembaharuan Pendidikan IPS. Bandung: PT. Remaja Rosdakarya.

Stoltz, P.G. 2000. Adversity Quotient. Mengubah Hambatan Menjadi Peluang. Jakarta: Grasindo.

Winarno, A. dan Saksono, Tri. 2001. Kecerdasan Emosional. Lembaga Administrasi Negara Republik Indonesia, Jakarta.

Winkel. 1991. Bimbingan dan Konseling di Institusi Pendidikan. Jakarta: Grasindo. 